\title{
Complexes of Some Transition Metal with 2-Benzoyl thiobenzimidazole and 1,10-Phenanthroline and Studying their Antibacterial Activity
}

Received 20/9/2015

Accepted 20/12/2015

cc) $($ () $\Theta$ This work is licensed under a Creative Commons Attribution-NonCommercialNoDerivatives 4.0 International Licens

\begin{abstract}
:
Mixed ligands of 2-benzoyl Thiobenzimiazole $\left(\mathrm{L}_{1)}\right.$ with 1,10-phenanthroline $\left(\mathrm{L}_{2}\right)$ complexes of $\mathrm{Cr}(\mathrm{III}), \mathrm{Ni}(\mathrm{II})$ and $\mathrm{Cu}(\mathrm{II})$ ions were prepared. The ligand and the complexes were isolated and characterized in solid state by using FT-IR, UV-Vis spectroscopy, ${ }^{1} \mathrm{H},{ }^{13} \mathrm{C}-\mathrm{NMR}$, flame atomic absorption, elemental micro analysis C.H.N.S, magnetic susceptibility, melting points and conductivity measurements. 2Benzoyl thiobenzimiazole behaves as bidenetate through oxygen atom of carbonyl group and nitrogen atom of imine group. From the analyses Octahedral geometry was suggested for all prepared complexes. A theoretical treatment of ligands and their metal complexes in gas phase were studied using HyperChem-8 program, moreover, ligands in gas phase also has been studied using Gaussian program (GaussView Currently Available Version (5.0.9) along with Gaussian 09 which was the latest in the Gaussian series of programs). The antibacterial activity of the prepared complexes have been determined and compared with that of the ligand and the standard metronidazole.
\end{abstract}

Key words: Mixed ligands, 1,10-Phenanthrolin, Theoretical treatment, Antibacterial activity.

\section{Introduction:}

The interaction of heterocyclic thiones with metals is still the topic of several studies as these ligands contain chemically effective groups and are advantageous model compounds for sulfur containing analogues of purine and pyrimidine bases. Heterocylic 2thiones bind to a metal in different ways, leading to the formation of monomeric or polymeric complexes [1]. Mercapto-1,3-azole ligands play an important role in industry and medicine [2,3]. One of their attractive characters is their acidity, which could affect their chemical reactivity toward transition metal ions and determine the complexes final structure [4]. 
The $2^{\text {nd }}$ National Conference of Chemistry

1,10-phenanthroline has been extensively used as ligand, due to their high chemical stability and their good coordination ability. This ligand coordinate easily to metal ions forming a stable ring with five atoms [5]. Metal complexes of phenanthroline chelators are of great interest since they exhibit numerous biological properties such as antitumor and antibacterial activity [6,7]

Mixed ligand complexes plays an important role in numerous chemical and biological systems like water softening, ion exchange resin, electroplating, dying, antioxidant, photosynthesis in plants, removal of undesirable and harmful metals from living organisms. Many of these metal complexes shown good biological activity against pathogenic microorganisms[8,9]. In this study has been devoted to prepared and characterize the mixing ligands and their metal complexes. In vitro antibacterial activity of all prepared compounds have also been performed.

\section{Materials and Methods:}

\section{A- Instrumentation:}

All chemicals and solvents used and were of highest purity obtained from Fulka, Merck and BDH. Melting point apparatus of Gallen Kamp M.F.B60 was employed to gauge the prepared compounds melting points, Elemental CHNS analysis were carried out on a<smiles>[R]Oc1ccc2[nH]c(SC(=O)c3ccccc3)nc2c1</smiles>

EM-017.mth instrument, the FT-IR spectra were recorded in range (4000$200 \mathrm{~cm}^{-1}$ ) as CsI disc on IR-Prestige-21, Single beam path Laser, Shimadzu Fourier Transform infrared Spectrophotometer, UV-Visible spectra were measured using UV-1800PC Shimadzu, in the range (190-1100) nm. The ${ }^{1} \mathrm{H},{ }^{13} \mathrm{C}$-NMR spectra were recorded on Burker $400 \mathrm{MHz}$ instrument using DMSO-d ${ }^{6}$ as solvent and TMS as internal reference in AL-Bayt University, Jordan. The magnetic susceptibility values of the prepared complexes were carried out in room temperature using Magnetic Susceptibility Balance of Johanson mattey catalytic system division. Atomic absorption measurements of the prepared complexes were obtained using Shimadzu Atomic Absorption 680 Flame Spectrophotometer. The conductance values of the prepared complexes were preformed using $0.001 \mathrm{M}$ Ethanol as a solvent, (WTW) Conductometer. The conventional method were used to prepare metal complexes.

\section{B- Synthesis of compounds}

\section{1- Preparation of 2-benzoyl} Thiobenzimiazole

According to the literature [10], The ligand 2-benzoyl Thiobenzimiazole prepared as in the following scheme :
2- Preperation of complexes by conventional method

A Solution containing primary ligand 2-benzoyl Thiobenzimiazole (0.254gm, $1 \mathrm{mmole})$ and secondary ligand 1,10phenanthroline $(0.198 \mathrm{gm}, 1 \mathrm{mmole})$ each dissolved in $5 \mathrm{ml}$ of absolute ethanol was added to a warm solution of metal salts (1mmole) of $\left[\mathrm{CrCl}_{3} .6 \mathrm{H}_{2} \mathrm{O}(0.26 \mathrm{~g})\right.$; $\mathrm{Ni}\left(\mathrm{NO}_{3}\right)_{2} \cdot 6 \mathrm{H}_{2} \mathrm{O}(0.29 \mathrm{~g}) ; \mathrm{Cu}\left(\mathrm{NO}_{3}\right)_{2} \cdot 3 \mathrm{H}_{2} \mathrm{O}$ $(0.24 \mathrm{~g})]$, in $10 \mathrm{ml}$ of absolute ethanol. The mixture was heated and refluxed with stirring for (3-4) hrs. The colored products was filtered, washed several 
times with ethanol, and dried using the electrical oven at $\left(65^{\circ} \mathrm{C}\right)$.

\section{Results and Discussion:}

The physio-chemical properties of the complexes are tabulated in Table (1).
The isolated solid complexes are stable at room temperature and soluble in Ethanol and most organic solvents. The spectroscopy and magnetic studies were used to confirm their formation and suggested geometry, (Tables 2 and 3 ).

Table (1): Some analytical and physical data of the ligands and their metal complexes.

\begin{tabular}{|c|c|c|c|c|c|c|c|c|}
\hline \multirow{2}{*}{ Compd. Colour } & \multirow{2}{*}{$\begin{array}{l}\text { Yield } \\
\%\end{array}$} & \multirow[t]{2}{*}{ M. p. ${ }^{\circ} \mathbf{C}$} & \multirow{2}{*}{$\begin{array}{l}\text { M. Wt } \\
\text { g.mol }\end{array}$} & \multicolumn{4}{|c|}{$\begin{array}{l}\text { \% Elemental micro analysis / Found } \\
\text { (Calc.) }\end{array}$} & \multirow{2}{*}{$\begin{array}{l}\text { Metal\% } \\
\text { Found } \\
\text { (Calc.) }\end{array}$} \\
\hline & & & & C & $\boldsymbol{H}$ & $N$ & $S$ & \\
\hline $\begin{array}{c}\mathbf{C}_{14} \mathbf{H}_{10} \mathbf{N}_{2} \mathbf{S O}(\mathbf{L 1}) \\
\text { Light yellow }\end{array}$ & 86 & $169-171$ & 254.00 & $\begin{array}{c}67.01 \\
(66.14)\end{array}$ & $\begin{array}{c}4.22 \\
(3.93)\end{array}$ & $\begin{array}{c}11.53 \\
(11.02)\end{array}$ & $\begin{array}{c}13.02 \\
(12.59)\end{array}$ & ----. \\
\hline $\begin{array}{c}\mathbf{C}_{12} \mathbf{H}_{8} \mathbf{N}_{2} \cdot \mathbf{H}_{2} \mathbf{O}(\mathbf{L} 2) \\
\text { White }\end{array}$ & --- & $100-102$ & 198.00 & (72.72) & (5.05) & (14.14) & ---- & ------- \\
\hline $\begin{array}{c}{\left[\mathrm{CrL}_{1} \mathbf{L}_{2} \mathbf{C l}_{2}\right] \mathbf{C l} .2 \mathrm{H}_{2} \mathrm{O}} \\
\text { Green }\end{array}$ & 72.70 & $146-148$ & 646.49 & $\begin{array}{c}48.29 \\
(48.26)\end{array}$ & $\begin{array}{c}3.86 \\
(3.71)\end{array}$ & $\begin{array}{c}8.68 \\
(8.66)\end{array}$ & $\begin{array}{l}4.95 \\
(4.94)\end{array}$ & $\begin{array}{c}7.99 \\
(8.04)\end{array}$ \\
\hline $\begin{array}{c}{\left[\mathrm{NiL}_{1} \mathbf{L}_{2} \mathrm{OH}_{2}\left(\mathrm{ONO}_{2}\right)\right] \mathrm{NO}_{3} .3 \mathrm{H}_{2} \mathrm{O}} \\
\text { Green }\end{array}$ & 83.25 & $180-182$ & 706.69 & $\begin{array}{c}44.03 \\
(44.14)\end{array}$ & $\begin{array}{c}3.10 \\
(3.67)\end{array}$ & $\begin{array}{c}11.77 \\
(11.88)\end{array}$ & $\begin{array}{c}4.44 \\
(4.52)\end{array}$ & $\begin{array}{c}7.97 \\
(8.30)\end{array}$ \\
\hline $\begin{array}{c}{\left[\mathrm{CuL}_{1} \mathrm{~L}_{2} \mathrm{OH}_{2}\left(\mathrm{ONO}_{2}\right)\right] \mathrm{NO}_{3} . \mathbf{1} / \mathbf{2} \mathrm{H}_{2} \mathrm{O}} \\
\text { Dark Blue }\end{array}$ & 84.37 & $150-152$ & 666.54 & $\begin{array}{c}47.45 \\
(46.80)\end{array}$ & $\begin{array}{c}3.43 \\
(3.45)\end{array}$ & $\begin{array}{c}12.68 \\
(12.60)\end{array}$ & $\begin{array}{c}4.68 \\
(4.80)\end{array}$ & $\begin{array}{l}10.00 \\
(9.53)\end{array}$ \\
\hline
\end{tabular}

\section{FT-IR Spectra:}

The most important infrared bands for the ligands and their complexes are reported in Table (2). The most important bands appeared in the spectrum of ligand $\mathrm{L}_{1}$, appeared at (1705; 1620; 784; and $1176 \mathrm{~cm}^{-1}$ ) which assigned to stretch frequency of $v(\mathrm{C}=\mathrm{O})$; $v(\mathrm{C}=\mathrm{N}) ; v(\mathrm{CS})$; and $v(\mathrm{CSC})$ respectively [11].

The spectra of metal complexes show that the band related to stretch frequency of $v(\mathrm{C}=\mathrm{O})$ was shifted to the lower or higher frequencies about (12 to $20 \mathrm{~cm}^{-1}$ ) in complexes, which indicate that the uncharged oxygen of carbonyl group take part in the coordination[11],more evidences new weak bands appeared in the spectra of complexes at lower frequencies about $\left(\sim 462-489 \mathrm{~cm}^{-1}\right)$ which assigned to $v$ (M-O) bond[15].Also the band related to the stretching frequency of $v(\mathrm{C}=\mathrm{N})$ was shifted to the lower frequency in $\mathrm{CrL}_{1} \mathrm{~L}_{2}$ about $\left(9 \mathrm{~cm}^{-1}\right)$ and to the higher in $\mathrm{CuL}_{1} \mathrm{~L}_{2}$ and $\mathrm{NiL}_{1} \mathrm{~L}_{2}$ frequencies about $\left(\sim 7-8 \mathrm{~cm}^{-1}\right)$. This means that the nitrogen of $(\mathrm{C}=\mathrm{N})$ group also coordinated with metal ion, a new weak bands were recorded at lower frequencies by $\left(\sim 563^{-570} \mathrm{~cm}^{-1}\right)$ which assigned to stretch frequency of $v(\mathrm{M}-\mathrm{N})$ bond was supported this coordinate[11,12].So, this ligand behaves as a bidenetate through (cyclic $\mathrm{N}$ and $\mathrm{O}$ ) atoms. Higher shifting frequencies related to the amide(II) in metal complexes, also $v(\mathrm{NH})$ group shift to higher in among $\mathrm{L}_{1}$ complexes due to the possible hydrogen bonding interaction between $(\mathrm{C}=\mathrm{O})$ and $(\mathrm{N}-\mathrm{H})$ moiety[11]. The presence of peaks that attributed to the aromatic $\mathrm{C}=\mathrm{C}$ and $\mathrm{C}=\mathrm{N}$ stretching of $\mathrm{L}_{2}$ around (1616-1419 $\mathrm{cm}^{-1}$ ) [11], so the spectra of the complexes show also characteristic bands which shifted and assigned to the stretching vibration of $v(\mathrm{C}=\mathrm{C}+\mathrm{C}=\mathrm{N})$ of co-ligand. The band at $\left(400 \mathrm{~cm}^{-1}\right)$ related to $(\mathrm{C}-\mathrm{C}$ out of plane bending) shifts to higher frequency and splits into two components in the complexes, which again confirms the coordination of coligand through two nitrogen, besides it shows bands at $\left(\sim 271-288 \mathrm{~cm}^{-1}\right)$ has also been observed in all the complexes indicating co-ligand nitrogen coordination with metal ions as (M$\mathrm{N})$ [12]. The spectrum of $\mathrm{CuL}_{1} \mathrm{~L}_{2}$ and $\mathrm{NiL}_{1} \mathrm{~L}_{2}$ exhibited bands which appeared at 1018, 1292, 1381 and $1427 \mathrm{~cm}^{-1} ; 783$, 1041,1234 and $1373 \mathrm{~cm}^{-1}$ respectively, probably attributed to the vibrations of 
The $2^{\text {nd }}$ National Conference of Chemistry

ionic and non-ionic nitrate group[11]. $\mathrm{CrL}_{1} \mathrm{~L}_{2}$ complex was observed band at $312 \mathrm{~cm}^{-1}$ due to the coordination of metal ion with chloride ions[11]. A broad band with maximum (3352-3448 $\mathrm{cm}^{-1}$ ) which assigned to lattice water as well as coordinated in coordination sphere.

Table (2):The most diagnostic FTIR of the ligands and their metal complexes in $\left(\mathrm{cm}^{-1}\right)$.

\begin{tabular}{|c|c|c|c|c|c|}
\hline Compd. & $\mathrm{L}_{1}$ & $\mathrm{~L}_{2}$ & {$\left[\mathrm{Cr} \mathrm{L}_{1} \mathrm{~L}_{2} \mathrm{Cl}_{2}\right] \mathrm{Cl} .2 \mathrm{H}_{2} \mathrm{O}$} & $\begin{array}{c}{\left[\mathrm{Ni} \mathrm{L}_{1} \mathrm{~L}_{2}\left(\mathrm{OH}_{2}\right)\left(\mathrm{ONO}_{2}\right)\right] \mathrm{NO}_{3}} \\
.3 \mathrm{H}_{2} \mathrm{O}\end{array}$ & $\begin{array}{c}{\left[\mathrm{CuL}_{1} \mathrm{~L}_{2}\left(\mathrm{OH}_{2}\right)\left(\mathrm{ONO}_{2}\right)\right] \mathrm{N}} \\
\mathrm{O}_{3} \cdot 1 / 2 \mathrm{H}_{2} \mathrm{O}\end{array}$ \\
\hline$v(\mathrm{~N}-\mathrm{H})$ & 3151 & ---- & 3140 & 3155 & 3150 \\
\hline$v(C=0)$ & 1705 & ---- & 1717 & 1689 & 1685 \\
\hline$v(C=N)$ & 1620 & ---- & 1611 & 1628 & 1627 \\
\hline$v(C=C)$ & 1504 & ---- & 1500 & 1516 & 1500 \\
\hline $\begin{array}{l}\mathrm{vC}-\mathrm{H} \\
\text { arom. }\end{array}$ & 3059 & 3059 & 3059 & 3080 & 3070 \\
\hline $\begin{array}{l}\delta(\mathrm{C}- \\
\mathrm{H})_{\text {oop }}\end{array}$ & $783,883,848$ & 802,731 & $883,848,806,783$ & $883,848,825$ & $875,848,823,802$ \\
\hline$\delta(\mathrm{C}-\mathrm{H})_{\text {ip }}$ & $\begin{array}{c}1234,1284,117 \\
6,1130 \\
\end{array}$ & $\begin{array}{c}1265,1202,1164 \\
1138,1033 \\
\end{array}$ & $\begin{array}{c}1284,1253,1234,1219,1199 \\
, 1176,1103 \\
\end{array}$ & $\begin{array}{c}1262,1234,1210,1200,1172 \\
, 1145,1103 \\
\end{array}$ & $\begin{array}{c}1292,1226,1203,1167,1 \\
149,1103 \\
\end{array}$ \\
\hline$v(\operatorname{CsC})$ & 1176 & ---- & 1199 & 1172 & 1149 \\
\hline$v(C S)$ & 748 & ----- & 752 & 752 & 750 \\
\hline $\begin{aligned} \mathrm{v}(\mathrm{C} & =\mathrm{N}+ \\
\mathrm{C} & =\mathrm{C})\end{aligned}$ & ----- & $\begin{array}{c}1616,1589,1558,1504,1 \\
446,1419\end{array}$ & $\begin{array}{c}1611,1600,1578 \\
1500,1470,1450,1423\end{array}$ & $\begin{array}{c}1628,1600,1585,1516 \\
1450,1427\end{array}$ & $\begin{array}{c}1619,1585,1500 \\
1458,1427\end{array}$ \\
\hline$v(M-N)$ & ----- & ------ & 565 & 570 & 563 \\
\hline$v(M-O)$ & ---- & ---- & 486 & 474 & 462 \\
\hline $\begin{array}{l}\mathrm{v}(\mathrm{M}- \\
\mathrm{N})_{\text {Phen }}\end{array}$ & ----- & ----- & 288 & 273 & 271 \\
\hline Others & ----- & $\mathrm{vH}_{2} \mathrm{O}=3410,3383$ & $\mathrm{vH}_{2} \mathrm{O}=3398$ & $\begin{array}{c}\mathrm{vH}_{2} \mathrm{O}=3352 \\
\mathrm{NO}_{3}=783,1041,1234,1373\end{array}$ & $\begin{array}{c}\mathrm{H}_{2} \mathrm{O}=3448 \\
\mathrm{NO}_{3}= \\
1018,1292,1381,1427\end{array}$ \\
\hline
\end{tabular}

Where oop $=$ out of plane, ip= in plane

\section{Electronic spectral, Magnetic moment} studies and Conductivity:

The electronic spectrum of $\mathrm{L}_{1}$ exhibited four main bands. The first and second absorption bands appeared at $\left(45871,40485 \mathrm{~cm}^{-1}\right)$ respectively due to $\left(\pi \rightarrow \pi^{*}\right)$ transition located on the $\mathrm{C}=\mathrm{C}$ group. The third and fourth absorption bands attributed to $\left(\mathrm{n} \rightarrow \pi^{*}\right)$ electronic transition may be located on the Nitrogen atom of the $-\mathrm{C}=\mathrm{N}$-group or Oxygen on $\mathrm{C}=\mathrm{O}$ group, which appeared at $\left(32786,29239 \mathrm{~cm}^{-1}\right)$ respectively $[10,13,14]$ as listed in Table (3).

The electronic Spectrum of co-ligand $\mathrm{L}_{2}$ show absorption band in the ultraviolet region at $\left(43859 \mathrm{~cm}^{-1}\right)$ due to the $\left(\pi \rightarrow \pi^{*}\right)$ transition for the interaligand aromatic system $(\mathrm{C}=\mathrm{C})$, and other absorption bands at (30959 and 38022) due to the $\left(n \rightarrow \pi^{*}\right)$ transition of imine group $(\mathrm{C}=\mathrm{N})$ [13].
Phen. = Phenanthroline

Cr(III) Complex: The spectrum of green $\mathrm{Cr}$ (III) consists of two bands observed at $17006,24390 \mathrm{~cm}^{-1}$ refers to ${ }^{4} \mathrm{~A}_{2} \mathrm{~g} \rightarrow{ }^{4} \mathrm{~T}_{2} \mathrm{~g} \quad, \quad{ }^{4} \mathrm{~A}_{2} \mathrm{~g} \rightarrow{ }^{4} \mathrm{~T}_{1} \mathrm{~g}_{(\mathrm{F})}$ transitions[15].The $v_{3}$ band calculated to be $38379 \mathrm{~cm}^{-1}$ which corresponding to ${ }^{4} \mathrm{~A}_{2} \mathrm{~g} \rightarrow{ }^{4} \mathrm{~T}_{1} \mathrm{~g}_{(\mathrm{p})}$ transition. The magnetic value 3.92 B.M. for Chromium (III) is observed, this value came in with published octahedral geometry around Cr(III) ion[16,17].

Ni(II) Complex: The electronic spectrum, shows two bands at 11001, $16233 \mathrm{~cm}^{-1}$ which assigned to ${ }^{3} \mathrm{~A}_{2} \mathrm{~g} \rightarrow{ }^{3} \mathrm{~T}_{2} \mathrm{~g},{ }^{3} \mathrm{~A}_{2} \mathrm{~g} \rightarrow{ }^{3} \mathrm{~T}_{1} \mathrm{~g}_{(\mathrm{F})}$ respectively and ${ }^{3} \mathrm{~A}_{2} \mathrm{~g} \rightarrow{ }^{3} \mathrm{~T}_{1} \mathrm{~g}_{(\mathrm{p})}$ transitions calculated and its found to be $27855 \mathrm{~cm}^{-1}$. These bands indicate an octahedral geometry around $\mathrm{Ni}(\mathrm{II})$ ion [18]. Magnetic measurement show to be 3.02 B.M and this came with published $\mathrm{Oh}$ around $\mathrm{Ni}(\mathrm{II})[15,19]$. 
The $2^{\text {nd }}$ National Conference of Chemistry

The diagrams of Tanabe-Sugano used to estimate the value of $v_{3}$ in the complexes of $\mathrm{Cr}$ (III) and $\mathrm{Ni}$ (II) ions. In addition to the calculation of values; $10 \mathrm{Dq}$, nephelauxetic factor $\beta$, Racah parameter $\mathrm{B}^{\prime}$ and $15 \mathrm{~B}^{\prime}$ Table (3).

$\mathrm{Cu}$ (II) Complex: The electronic spectrum, show broad absorption band at $14814 \mathrm{~cm}^{-1}$ which assigned to ${ }^{2} \mathrm{Eg} \rightarrow{ }^{2} \mathrm{~T}_{2} \mathrm{~g}$ and other bands at $36630,43478 \mathrm{~cm}^{-1}$ which related to charge transfer transitions. Magnetic measurement showed to be 1.85 B.M and this came with published Octahedral around $\mathrm{Cu}(\mathrm{II})[20]$.

The conductance measurements indicate that the ionic behavior for all prepared complexes as illustrated in Table (3).

NMR spectra for ligand

\section{${ }^{1}$ H-NMR spectrum}

${ }^{1} \mathrm{H}-\mathrm{NMR}$ spectrum for ligand by using DMSO solvent showed band at the range (2.415-2.511)ppm which due to the protons of solvent and multiple bands appear at the range (7.185-7.839) ppm return to the aromatic ring protons while the NH Group showed one band at the position (12.55) ppm.

\section{${ }^{13} \mathrm{C}-\mathrm{NMR}$ spectrum}

${ }^{13} \mathrm{C}-\mathrm{NMR}$ spectrum for ligand by using DMSO solvent showed multi bands at the range (38.63-43.79)ppm which return to the carbon of the following groups $2 \mathrm{C}-\mathrm{S}, 1 \mathrm{C}=\mathrm{N}, 1 \mathrm{C}-\mathrm{N}$ and multi bands appear at the range (122.27-134.98) ppm assigned to the aromatic ring carbons while the carbonyl group showed four bands at the range (168.71-169.84) ppm.

Table (3): Electronic spectra, Conductance in Ethanol solvent and magnetic moment (B.M) for the ligands and their metal complexes.

\begin{tabular}{|c|c|c|c|c|c|}
\hline Compd. & $\mathbf{L}_{1}$ & $\mathbf{L}_{2}$ & $\begin{array}{c}{\left[\mathrm{Cr} \mathrm{L}_{1} \mathrm{~L}_{2} \mathrm{Cl}_{2}\right] \mathrm{Cl}} \\
.2 \mathrm{H}_{2} \mathrm{O}\end{array}$ & 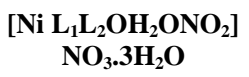 & $\begin{array}{c}{\left[\mathrm{CuL}_{1} \mathrm{~L}_{2} \mathrm{OH}_{2} \mathrm{ONO}_{2}\right]} \\
\mathrm{NO}_{3.1} \cdot \mathbf{1} / 2 \mathrm{H}_{2} \mathrm{O}\end{array}$ \\
\hline $\begin{array}{c}\text { Absorption } \\
\text { Bands cm } \\
{ }^{1}(\mathrm{~nm})\end{array}$ & $\begin{array}{l}29239(342) \\
32786(305) \\
40485(247) \\
45871(218)\end{array}$ & $\begin{array}{l}30959(323) \\
38022(263) \\
43859(228)\end{array}$ & $\begin{array}{c}17006(588) \\
24390(410) \\
38379 \\
(260)_{\text {cal. }}\end{array}$ & $\begin{array}{c}11001(909) \\
16233(616) \\
27855(359)_{\text {cal. }}\end{array}$ & $\begin{array}{l}14814(675) \\
36630(273) \\
43478(230)\end{array}$ \\
\hline Assignments & $\begin{array}{c}\mathrm{n} \rightarrow \pi_{*} \\
\pi \rightarrow \pi_{*}\end{array}$ & $\begin{array}{l}\mathrm{n} \longrightarrow \pi_{*} \\
\pi \longrightarrow \pi_{*}\end{array}$ & $\begin{array}{l}{ }^{4} \mathrm{~A}_{2} \mathrm{~g} \rightarrow{ }^{4} \mathrm{~T}_{2} \mathrm{~g} \\
{ }^{4} \mathrm{~A}_{2} \mathrm{~g} \rightarrow{ }^{4} \mathrm{~T}_{1} \mathrm{~g}_{(\mathrm{F})} \\
{ }^{4} \mathrm{~A}_{2} \mathrm{~g} \rightarrow{ }^{4} \mathrm{~T}_{1} \mathrm{~g}_{(\mathrm{P})}\end{array}$ & $\begin{array}{c}{ }^{3} \mathrm{~A}_{2} \mathrm{~g} \rightarrow{ }^{3} \mathrm{~T}_{2} \mathrm{~g} \\
{ }^{3} \mathrm{~A}_{2} \mathrm{~g} \rightarrow{ }^{3} \mathrm{~T}_{1} \mathrm{~g}_{(\mathrm{F})} \\
{ }^{3} \mathrm{~A}_{2} \mathrm{~g} \rightarrow{ }^{3} \mathrm{~T}_{1} \mathrm{~g}_{(\mathrm{P})}\end{array}$ & $\begin{array}{c}{ }^{2} \mathrm{Eg} \rightarrow{ }^{2} \mathrm{~T}_{2} \mathrm{~g} \\
\mathrm{ILCT} \\
\text { ILCT }\end{array}$ \\
\hline$B^{\circ}\left(\mathrm{cm}^{-1}\right)$ & & & 918 & 1035 & \\
\hline$B^{\prime}\left(\mathrm{cm}^{-1}\right)$ & & & 811 & 739 & \\
\hline $\boldsymbol{B}$ & & & 0.88 & 0.71 & \\
\hline$D q / B^{\prime}\left(\mathrm{cm}^{-1}\right)$ & & & 2.00 & 1.45 & \\
\hline $10 D q\left(\mathrm{~cm}^{-1}\right)$ & & & 16220 & 10715 & \\
\hline $15 B^{\prime}\left(\mathrm{cm}^{-1}\right)$ & & & 12165 & 11085 & \\
\hline$\lambda^{\prime}\left(\mathrm{cm}^{-1}\right)$ & & & & -180 & \\
\hline$\mu_{\text {eff }}$ B.M. & & & 3.92 & 3.02 & 1.85 \\
\hline$\mu$ H.cm ${ }^{-1}$ & & & 36.3 & 40.1 & 42.2 \\
\hline $\begin{array}{l}\text { Suggested } \\
\text { geometry }\end{array}$ & & & Oh & Oh & Oh \\
\hline
\end{tabular}




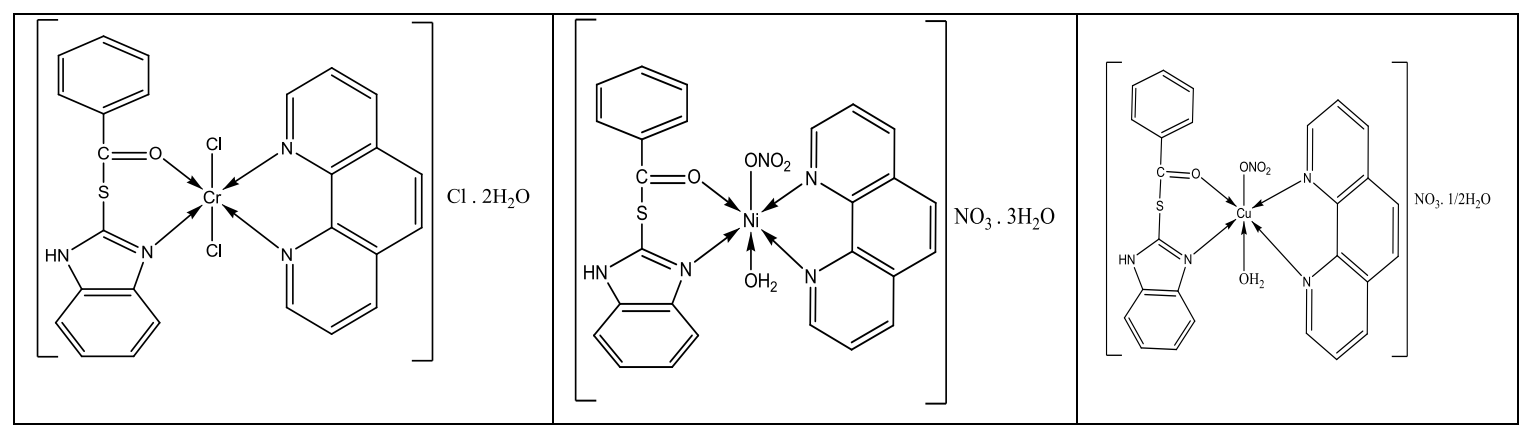

Fig. (1): Suggested structure of the prepared complexes.

\section{Theoretical Studies:}

In this work, Hyperchem-8 program was used to calculate the heat of formation $\left(\Delta \mathrm{H}_{\mathrm{f}}^{\mathrm{o}}\right)$, binding energy $\left(\Delta \mathrm{E}_{\mathrm{b}}\right)$ and dipole moment $(\mu)$ for the free ligands and their metal complexes using semi-empirical (ZINDO/I \& PM3) and molecular mechanics (AMBER) methods at 298K [21]. It was found that the complexes are more stable than the ligands Table (4). Furthermore, the electrostatic potential for free ligands was calculated to investigate the reactive site of the molecules Figure (2),PM3 was used to evaluate the vibrational spectra of free ligands. It has been found that these obtained frequencies agree well with the experimental results ; in addition, the calculation helped to assign unambiguously the most diagnostic bands, Table (6,7).Electronic spectra measurements for the ligands was calculated theoretically by using ZINDO/S method and comparing it with experimental results. It was found that there was a close agreement between the theoretical calculation and experimental results Table (8). While Gaussian program semi-empirical (PM3) method was used to calculate, the geometry optimization, dipole moment $(\mu)$ and total energy as shown in Table (5), electrostatic potential, $\mathrm{E}_{\mathrm{LUMO}}$ and $\mathrm{E}_{\mathrm{HOMO}}$ was obtained Figure (2) and evaluate the vibrational spectra by PM3 as above mentioned Table (6,7).Electronic spectra measurements for the ligands was calculated theoretically by using the job type : Single point energy (SP) along with ZINDO method and also along with CIS method (3-21G) Table (9).

Table (4): Conformation energetic (in K.J.mol ${ }^{-1}$ ) and dipole moment (in Debye) for ligands and their metal complexes using HyperChem-8 program.

\begin{tabular}{|c|c|c|c|c|c|c|}
\hline \multirow{2}{*}{ Comp. } & \multicolumn{3}{|l|}{ PM3 } & \multicolumn{3}{|l|}{ ZINDO/1 } \\
\hline & $\Delta \mathbf{H}_{\mathrm{f}}^{\circ}$ & $\Delta \mathbf{E}_{\mathrm{b}}$ & $\mu$ & $\Delta \mathbf{H}_{\mathbf{f}}^{\circ}$ & $\Delta \mathbf{E}_{\mathrm{b}}$ & $\mu$ \\
\hline $\mathbf{L}_{1}$ & 303.9117786 & -13358.685 & 6.968 & 26522.21357 & 40184.81035 & 9.906 \\
\hline $\mathbf{L}_{2}$ & 298.3251322 & -10971.26213 & 2.991 & 22179.41782 & 33449.00509 & 3.931 \\
\hline $\operatorname{CrL}_{1} \mathbf{L}_{2}$ & --------- & --------- & ----- & 50260.82068 & 75833.07304 & 14.85 \\
\hline $\mathrm{NiL}_{1} \mathbf{L}_{2}$ & -------- & ------- & ---- & 53842.76836 & 81110.62856 & 7.556 \\
\hline $\mathrm{CuL}_{1} \mathrm{~L}_{2}$ & -------- & -------- & ---- & 54229.48008 & 81404.87388 & 7.006 \\
\hline
\end{tabular}


The $2^{\text {nd }}$ National Conference of Chemistry

Table (5): Conformation energetic in (in K.J.mol ${ }^{-1}$ ) and dipole moment (in Debye) for ligands using Gaussian program.

\begin{tabular}{|c|c|c|}
\hline Ligand & Total energy & $\boldsymbol{\mu}$ \\
\hline $\mathrm{L}_{1}$ & 228.7938415 & 4.4212 \\
\hline $\mathrm{L}_{2}$ & 299.1957838 & 2.9937 \\
\hline
\end{tabular}

Table (6):Comparison of experimental and theoretical vibrational frequencies for primary ligand by HyperChem8 and Gaussian programs.

\begin{tabular}{|c|c|c|c|c|c|c|c|}
\hline \multicolumn{2}{|c|}{ Ligand } & vC=O & vC=N & vC-S & vN-H & vC=C & $\begin{array}{c}\text { vC-H } \\
\text { aromatic }\end{array}$ \\
\hline \multirow{4}{*}{$\mathrm{L}_{1}$} & Exp. & $1705^{*}$ & $1620^{*}$ & $748^{*}$ & $1504^{*}$ & $1504^{*}$ & $3059^{*}$ \\
\cline { 2 - 8 } & \multirow{2}{*}{ Hyper. } & 1902.24 & 1566.56 & 690.35 & 1502.68 & 1502.68 & 3075.10 \\
\cline { 2 - 8 } & \multirow{2}{*}{ Gass. } & $(11.568)$ & $(-3.298)$ & $(-7.707)$ & $(-0.087)$ & $(-0.087)$ & $(0.526)$ \\
\hline
\end{tabular}

Table (7):Comparison of experimental and theoretical vibrational frequencies for co-ligand by HyperChem8 and Gaussian programs.

\begin{tabular}{|c|c|c|c|c|}
\hline \multicolumn{2}{|c|}{ Ligand } & $\mathbf{v}(\mathbf{C}=\mathbf{N}+\mathbf{C}=\mathbf{C})$ & $\mathbf{v}(\mathbf{C}-\mathbf{H})$ aromatic & $\boldsymbol{\delta}(\mathbf{C}-\mathbf{N})$ \\
\hline \multirow{4}{*}{$\mathbf{L}_{2}$} & Exp. & $1616^{*}$ & $2981^{*}$ & $1446^{*}$ \\
\cline { 2 - 5 } & \multirow{2}{*}{ Hyper. } & 1760.93 & 3063.20 & 1395.01 \\
& \multirow{2}{*}{ Gass. } & $(8.968)$ & $(2.757)$ & $(-3.526)$ \\
\cline { 2 - 5 } & 1697.77 & 3031.80 & 1518.71 \\
& $(5.060)$ & $(1.704)$ & $(5.028)$ \\
\hline
\end{tabular}

Where:* : Experimental frequency

: Theoretical frequency

( ) : Error \% due to main different in the experimental measurements and theoretical treatment of vibrational frequency.

Table (8): Ultra violet spectra of ligands from ZINDO/S calculation and experiment data using HyperChem8 program.

\begin{tabular}{|c|c|c|c|}
\hline Ligand & Transition & Experimental & Theoretical (ZINDO/S) \\
\hline \multirow{3}{*}{$\mathbf{L}_{\mathbf{1}}$} & $\mathrm{n} \rightarrow \pi^{*}$ & $29239(342)$ & 343 \\
& $\mathrm{n} \rightarrow \pi^{*}$ & $32786(305)$ & 303 \\
& $\pi \rightarrow \pi^{*}$ & $40485(247)$ & 228 \\
& $\pi \rightarrow \pi^{*}$ & $45871(218)$ & ---- \\
\hline & $\mathrm{n} \rightarrow \pi^{*}$ & $30959(323)$ & ----- \\
$\mathbf{L}_{\mathbf{2}}$ & $\mathrm{n} \rightarrow \pi^{*}$ & $38022(263)$ & 278 \\
& $\pi \rightarrow \pi^{*}$ & $43859(228)$ & 218 \\
\hline
\end{tabular}

Table (9): Comparison of experimental and theoretical electronic transition for ligands from CIS and ZINDO calculation and experiment method using Gaussian program.

\begin{tabular}{|c|c|c|c|c|}
\hline \multirow{2}{*}{ Ligand } & Transition & \multirow{2}{*}{ Experimental } & \multicolumn{2}{|c|}{ Theoretical } \\
\cline { 3 - 5 } & $\mathrm{n} \rightarrow \pi^{*}$ & $29239(342)$ & & \\
& $\mathrm{n} \rightarrow \pi^{*}$ & $32786(305)$ & \multirow{2}{*}{ ZINDO } \\
\hline \multirow{2}{*}{$\mathbf{L}_{\mathbf{1}}$} & $\pi \rightarrow \pi^{*}$ & $40485(247)$ & & 303.7 \\
& $\pi \rightarrow \pi^{*}$ & $45871(218)$ & & \\
& $\mathrm{n} \rightarrow \pi^{*}$ & $30959(323)$ & & \\
$\mathbf{L}_{\mathbf{2}}$ & $\mathrm{n} \rightarrow \pi^{*}$ & $38022(263)$ & 223.64 & 311.26 \\
& $\pi \rightarrow \pi^{*}$ & $43859(228)$ & & \\
\hline
\end{tabular}


The $2^{\text {nd }}$ National Conference of Chemistry

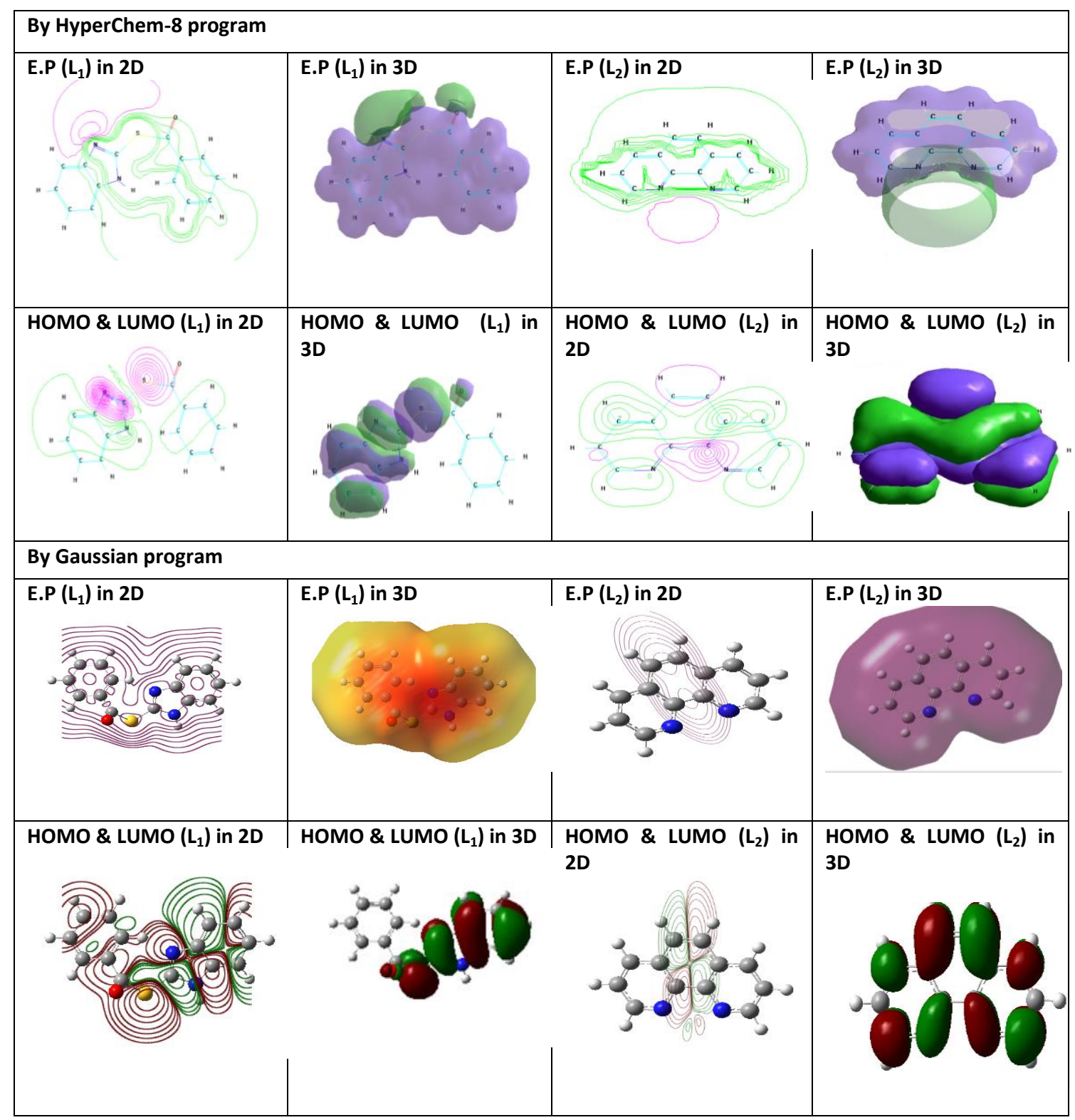

Fig. (2): HOMO,LUMO \& electrostatic potential as 2\&3D counters for ligands.

Bactericidal activity of the standard (metronidazole), $\mathrm{L}_{1}$ and synthesized metal complexes

Antibacterial activity of the prepared ligand and its metal complexes were tested in vitro for antibacterial activity according to the disk diffusion method [22] against the following pathogenic microorganism : Staphylococcus aureus (Gram-positive bacteria) and Pseudomonas aeruginosa, E.Coli and Salmonella (Gram-negative bacteria), the prepared agar and petridishes were sterilized by autoclaving for $(15 \mathrm{~min})$ at $121^{\circ} \mathrm{C}$. the agar plates were surface inoculated uniformly from the broth culture of the lested microorganisms. In the solidified medium suitable spaced apart holes were made all $(6 \mathrm{~mm})$ in diameter compounds $(0.01 \mathrm{mg}$ of the compounds dissolved in $10 \mathrm{ml}$ of ethanol solvent).

These plates were incubated at $37^{\circ} \mathrm{C}$ for $24 \mathrm{hrs}$, the inhibition zones caused by the various compounds on the bacteria were examined. The results of the preliminary screening test are listed in Figure (3). The data reveal that some complexes have higher activities other have lower than free ligand. These results indicate that the degree of growth 
The $2^{\text {nd }}$ National Conference of Chemistry

inhibition is highly dependent on (i) the nature of donor atoms (ii) the nature of the metal ion (iii) the chelate effect of the ligand (iv) the total charge on the complex ion (v) the geometrical structure of the complexes (vi) the nature of the counter ions that the neutralize the complex [23]. The chelating theory considerably reduces the polarity of the metal ion mainly because of partial partnershipe of positive charge with the donor groups and possible electron delocalization over the whole chelating ligand. Such coordination could also enhance the lipophilic character of the central metal atom, which subsequently favours its permeation through the lipid layer of the cell membranes[24].

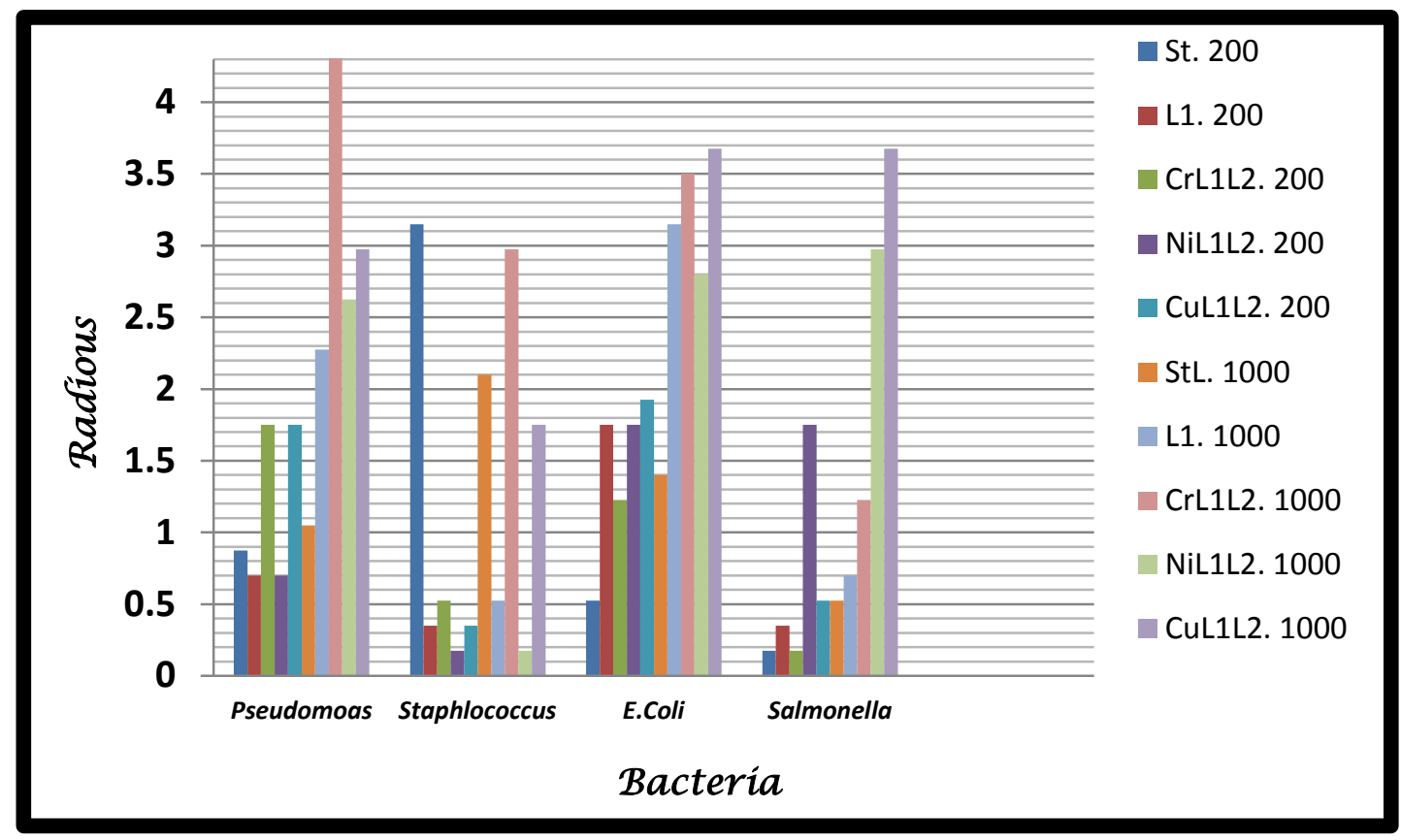

Fig. (3): Antibacterial activities for standard (metronidazole), $L_{1}$ and their metal complexes

\section{References:}

[1] Tarlok, S.; Renu, V.; Geeta, H. and Alfonso, C., $2000 . \quad$ Metalheterocyclic thione interactions. 12. Heterocyclic 2-thiolates of platinum(II) and palladium(II): the crystal structures of first examples of cis- $\left[\mathrm{M}(\mathrm{h} 1-\mathrm{S}-\mathrm{pyridine}-2 \text { thiolato })_{2}(\mathrm{~L}-\right.$ L)] $\quad\{\mathrm{M}=\mathrm{Pt}, \quad \mathrm{Pd}, \quad \mathrm{L}-\mathrm{L}=1,2-$ bis(diphenylphosphino)ethane; $\mathrm{M}=\mathrm{Pt}$, L-L=1,2-

bis(diphenylphosphino)ethene complexes Polyhedron 19(8), 899906

[2] Husain, A.; Varshney, M.; Rashid, M. and Akhter, A., 2011. benzimidazole: A Valuable Insight into the recent Advances and
Biological Activities ,J. Pharm. Rese.,4(2),413- 419

[3] Papagiannopoulou, D.; Pirmettis, I. C.; Pelecanou, M.; Tsoukalas, Ch.; Raptopoulou, C. P.; Terzis, A.; Chiotellis, E. and Papadopoulos, M., 2001. Synthesis and structural characterization of a novel $\mathrm{Re}[\mathrm{P}][\mathrm{NN}][\mathrm{S}][\mathrm{SO}]$ mixed ligand rhenium (III) complex.

Inorganica Chimica Acta, 320(1): 174-177.

[4] Li , X-H.; Tang, Z-X. and Zhang, XZ., 2009. Molecular structure, IR spectra of 2-

mercaptobenzothiazole and 2mercaptobenzoxazole by density functional theory and ab initio 
Hartree-Fock calculations.

Spectrochimica Acta Part A: Molecular and Biomolecular Spectroscopy. 74(1), 168-173.

[5] Mirela, C.; Daniela, M. and Gabriela, P., 2011. Synthesis and spectroscopic properties of new complex compounds of europium(III) and terbium(III)with 2-hydroxy-1naphthal-dehyde acetylhydrazone and heterocyclic bases. Rev. Roum. Chim.56(3):231-237.

[6] Deegan, C.; McCann, M.; Devereux, M.; Coyle, B. and Egan, D., 2007. Invitro cancer chemotherapeutic potential and mechanism of action of 1,10-phenanthroline (phen), [Ag2(phen)3(mal) $] \times 2 \mathrm{H} 2 \mathrm{O}$, $[\mathrm{Cu}($ phen $) 2($ mal $)] \times 2 \mathrm{H} 2 \mathrm{O}$ and $[\mathrm{Mn}($ phen $) 2(\mathrm{mal})] \times 2 \mathrm{H} 2 \mathrm{O}(\mathrm{malH} 2=$ malonic acid), using human cancer cells. Cancer Lett. 247(2): 224-233.

[7] McCann, M.; Geraghty, M.; Devereux, M.; O'Shea, D.; Mason, J. and O'Sullivan, L., 2000. Insights into the mode of action of the antiCandida activity of 1,10phenanthroline and its metal chelates. Met Based Drugs.,7(4):185-193.

[8] Sanap, S. and Patil, R., 2013. Synthesis, Characterization and Biological Activity of Chiral Mixed Ligand Ni(II) Complexes.Res. J. Pharmaceutical Sci.2(1): 1-10.

[9] Halli, M. B.; Vijayalaxmi, B. P.; Sumathi, R. B. and Kinni, M., 2012. Synthesis, charact- terization and biological activity of mixed ligand metal (II) complexes derived from benzofuran-2-carbohydrazide schiff base and malonyldihydrazide. Der Pharma Chemica.4(6):2360-2367.

[10] Alias, M. F. and Mahal, D. H., 2015. Synthesis, Structural Diagnosis, Theoretical Treatment and Antibacterial Study of Pd(II), Rh(III), $\mathrm{Pt}(\mathrm{IV})$ and $\mathrm{Au}(\mathrm{III})$ Complexes Containing 2-(PNitroBenzoyl) Thio Benzimidazole. International Journal of Science and Research ,4(7): 14691476.

[11] Nakomato, N., 2009. Infrared and Raman Spectra of Inorganic and Coordination Compounds. $6^{\text {th }}$.ed., John Wiley and Sons, Inc., New Jersey.

[12] Chaudhary, R. and Shelly, 2011. Synthesis, Spectral and Pharmacological Study of $\mathrm{Cu}(\mathrm{II})$, $\mathrm{Ni}$ (II) and $\mathrm{Co}(\mathrm{II})$ Coordination Complexes Res. J. Chem. Sci. 1(5): 1-5.

[13] Sliverstein, R. M.; Bassler, G. C. and Marril, T. C., 1981. Spectrometric Identification of Organic Chemistry, John Wiley and Sons,

[14] Kumar, R.; Mahiya, K. and Mathur, P., 2011. Synthesis, spectral and structural characterization of $\mathrm{Cu}(\mathrm{II})$ complexes of atridentate NNO donor Schiff base carrying apendant benzimidazolyl arm, Ind.J.Chem.50(A):775-780.

[15] Figgis, B. and Hitchman, M., 2000. Ligand Field Theory and Its Applications. Wiley, New York.

[16] Lever, A. B. P., 1968. Inorganic Electronic Spectroscopy, Amsterdam -London- New York,

[17] Mishra, A. P. and Jain, R .K., 2010. Microwave synthesis, spectroscopic, thermal and biological significance of some transition metal complexes containing heterocyclic ligands" J.Chem. Pharm. Res ,2(6): 51-61.

[18] Eittah, R. A.; Hamed, M.; El. Makabaty, S., 1983. Synthesis, spectral characterization, structural studies and biological investigations of transition metal complexes, Trans. Met. Chem., 8(2):198.

[19] Dissouky, A. and Mohamed, G. B., 1984. Metal chelates of heterocyclic nitrogen containing ketones, XIII. Cobalt(II), nickel(II) and palladium(II) complexes of 2-picolyland 2-lutidyl-methyl ketones" Transition Met. Chem., 9(1):23-28 . 
[20] (a) Mishra, A. P. and Jain, R. 2012. Microwave Assisted Synthesis, Spectroscopic, Thermal and Antimicrobial Studies of Some Transition Metal Complexes of Schiff Base Ligands Containing Thiazole Moiety, Jord. J. Chem., 7(1): 9-21.

(b) Jasim, U. Z. 2011. Synthesis and Characterization of New Mn(II), $\mathrm{Co}(\mathrm{II}), \mathrm{Ni}(\mathrm{II})$ and $\mathrm{Cu}(\mathrm{II})$ Complexes with [a-methyl-N-(3-methylidene indol)-2-amino anthraquinone] Ligand, College of Basic Edu. Res. J., 10(4):570-581
[21] Young, D. C. 2001. Computational Chemistry, John Wiley \& Sons.

[22] Laura, .J.V.P. 1990. Techniques used for the determination of antimicrobial resistance and sensitivity in bacteria, J.Applied Bacteriology; 68(4):307-318.

[23] Marcela, R., 2012. Metal Complexes as Antimicrobial Agents, INTECH 73-88.

[24] Yousif, Q. I. and Alias, F. M., 2013. Synthesis, structural study, Antimicrobial activity and theoretical treatment of 3d-metal complexes involving Schiff base of piperonal derivative AJPS, 13(1): 1-13 .

\section{معقدات بعض الفلزات الاتثقالية مع 2- بنزويل ثايوينزاميدازول و10-10

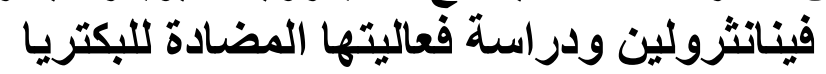

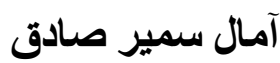

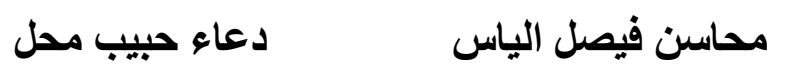 \\ قسم الكيمياء، كلية العلوم للبنات، جامعة بغداد، بغداد، العراق}

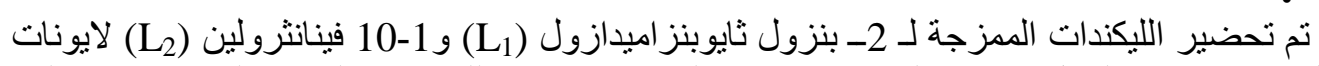

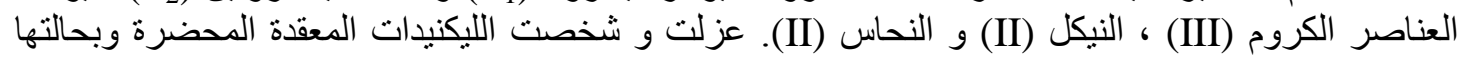

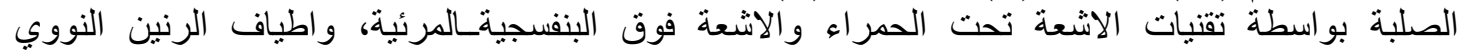

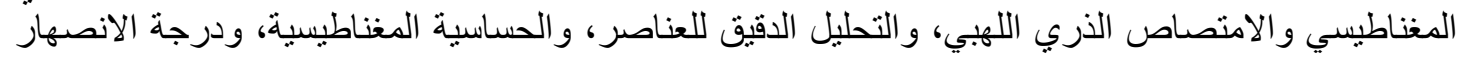

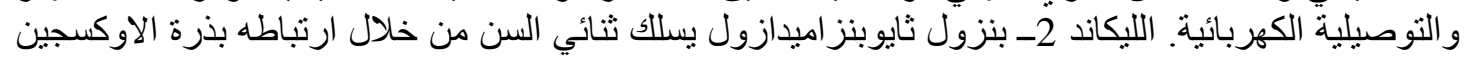

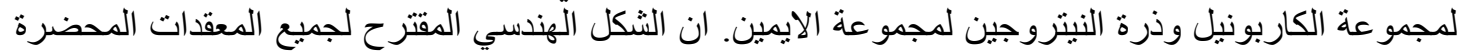

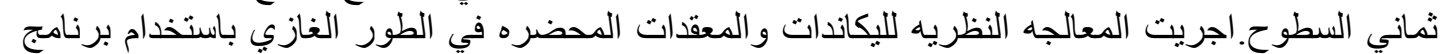

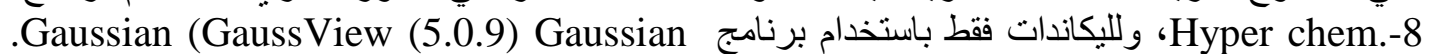

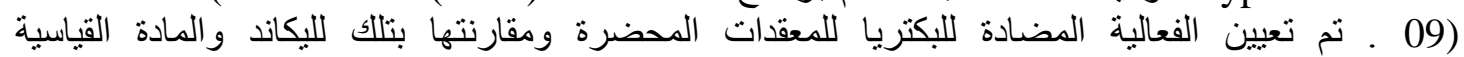
المنرونيدازول .

الكلمات المفتاحية: الليكاندات المززوجة، 101 - فينانثرولين، المعالجة النظرية، الفعالية المضادة للبكتريا. 